\title{
Adjuvants in Allergen-Specific Immunotherapy: Modulating and Enhancing the Immune Response
}

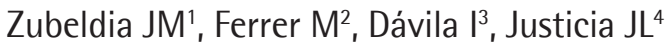 \\ 1'Allergy Service, Hospital General Universitario Gregorio Marañón; Gregorio Marañón Health Research Institute (liSGM); Biomedical Research \\ Network on Rare Diseases (CIBERER)-U761, Madrid, Spain \\ ${ }^{2}$ Department of Allergy, Clínica Universidad de Navarra; Department of Medical Education, School of Medicine, Navarra University, Pamplona, \\ Spain and Instituto de Investigación Sanitaria de Navarra (IdiSNA); RETIC de Asma, Reacciones adversas y Alérgicas (ARADYAL) \\ ${ }^{3}$ Allergy Service, University Hospital of Salamanca; Department of Biomedical and Diagnostic Sciences, School of Medicine, University of \\ Salamanca; Institute for Biomedical Research of Salamanca, Salamanca; Spain; RETIC de Asma, Reacciones adversas y Alérgicas (ARADYAL) \\ ${ }^{4}$ Medical Department, Allergy Therapeutics Ibérica, Alcalá de Henares, Spain
}

J Investig Allergol Clin Immunol 2019; Vol. 29(2): 103-111

doi: 10.18176/jiaci.0349

\begin{abstract}
Allergen-specific immunotherapy (AIT) is the only treatment that can affect the natural course of allergic diseases such as allergic asthma, allergic rhinitis, and IgE-mediated food allergy. Adjuvants are used to induce a quicker, more potent, and longer-lasting immune response. Only 4 compounds are used as adjuvants in currently marketed AIT products: aluminum hydroxide, calcium phosphate, microcrystalline tyrosine (MCT), and monophosphoryl lipid A (MPL). The first 3 adjuvants are delivery systems with a depot effect, although they may also have immunomodulatory properties. These first-generation adjuvants are still widely used, especially aluminum hydroxide. However, aluminum is subject to limitations. MCT is the depot formulation of L-tyrosine; it enhances IgG production without inducing a significant increase in $\mathrm{lg} \mathrm{E}$, is biodegradable, and has good local and systemic tolerability. In turn, MPL is an immunostimulatory agent that is the only second-generation adjuvant currently used for AIT. In addition, multiple adjuvants are currently being studied, including immunostimulatory sequences (ISSS), nanoparticles (liposomes, virus-like particles, and biodegradable polymers), and phosphatidylserine derivatives.

In a murine model of allergic bronchial inflammation by sensitization to olive pollen, the specific IgE level was significantly higher in sensitized mice treated with olive pollen and aluminum hydroxide. However, specific lgE levels were significantly reduced and bronchial hyperreactivity significantly improved in sensitized mice treated with olive pollen and bacterial derivatives (MPL or ISSS).
\end{abstract}

Key words: Asthma. Allergen-specific immunotherapy. Adjuvant. Aluminum hydroxide. Calcium phosphate. Microcrystalline tyrosine. Monophosphoryl lipid A. Immunostimulatory sequences. Nanoparticles.

\section{Resumen}

La inmunoterapia específica con alérgenos (ITE) es el único tratamiento con potencial para modificar la evolución natural de enfermedades alérgicas como el asma alérgica, la rinitis alérgica y la alergia a alimentos mediada por lgE. Los adyuvantes se usan para provocar una respuesta inmune más rápida, más potente y de mayor duración.

Hasta ahora, solo cuatro compuestos se usan como adyuvantes en los productos de ITE comercializados actualmente: hidróxido de aluminio, fosfato cálcico, tirosina microcristalina (MCT) y monofosforil lípido A (MPL). Los tres primeros son sistemas de liberación retardada (efecto depot), aunque también podrían tener propiedades inmunomoduladoras. Estos adyuvantes de primera generación todavía se usan ampliamente, sobre todo el hidróxido de aluminio. Sin embargo, el aluminio tiene algunas limitaciones. MCT es la formulación de liberación retardada de la L-tirosina; aumenta la producción de IgG sin provocar un incremento significativo de lgE, es biodegradable y tiene una buena tolerabilidad local y sistémica. A su vez, MPL es un inmunoestimulador y es el único adyuvante de segunda generación usado actualmente en ITE. Además, hay múltiples adyuvantes en investigación, como las secuencias inmunoestimuladoras (SIE), nanopartículas (liposomas, partículas similares a virus y polímeros biodegradables) y derivados de la fosfatidilserina.

En un modelo múrido de inflamación bronquial alérgica por sensibilización al polen de olivo, el nivel de lgE específica fue significativamente mayor en los animales sensibilizados tratados con polen de olivo e hidróxido de aluminio. Sin embargo, en los animales sensibilizados tratados con polen de olivo y derivados bacterianos (MPL o SIE) se observó una disminución significativa del nivel de lgE específica y una mejoría significativa de la hiperreactividad bronquial.

Palabras clave: Asma. Inmunoterapia específica con alérgenos. Adyuvante. Hidróxido de aluminio. Fosfato cálcico. Tirosina microcristalina. Monofosforil lípido A. Secuencias inmunoestimuladoras. Nanopartículas. 


\section{Introduction}

Allergen-specific immunotherapy (AIT) is the only disease-modifying therapy for allergic asthma, allergic rhinoconjunctivitis, and other allergic conditions [1]. Its aim is to induce a tolerogenic response against the allergen of interest [2]. Recent systematic reviews and meta-analyses have confirmed that AIT is effective in reducing symptoms and medication needs in patients with allergic asthma [3] and rhinoconjunctivitis [4]. Moreover, AIT reduces the risk of developing asthma, at least in the short term, in patients with allergic rhinitis [5]. AIT is also effective in patients with IgE-mediated food allergy [6] and insect venom allergy [7].

\section{Mechanism of Action of Allergen-Specific Immunotherapy}

AIT mechanisms are not fully understood. Based on current knowledge, effective AIT sequentially activates multiple mechanisms and induces cellular and molecular changes (Figure 1). This complex mechanism of action of AIT occurs in 3 phases: rapid desensitization, early tolerance, and sustained tolerance [8]. Rapid desensitization is characterized by an early fall in degranulation of mast cells and basophils, probably due to rapid upregulation of histamine type 2 receptor. The second phase, early tolerance, includes a decrease in interleukin (IL) 4-secreting $\mathrm{T}_{\mathrm{H}} 2$ cells and increases in IL-10-secreting Treg cells and Breg cells. There is a switch from a $\mathrm{T}_{\mathrm{H}} 2$-type response to a $T_{H} 1$-type response, with increases in IL-10 and transforming growth factor $\beta$ production. There is also an increase in Treg cells that correlates with clinical improvement. Finally, sustained tolerance implies that Treg cells stimulate B cells to produce allergen-specific IgG4, a tolerogenic highaffinity blocking antibody that competes with allergen-specific IgE, thus avoiding the allergen-induced release of mediators by mast cells and basophils. These sequentially activated mechanisms induce immune tolerance that attenuates or even abolishes both the acute (early) phase of allergic reaction and any subsequent immunologic event [8].

\section{Adjuvants in Allergen-Specific Immunotherapy}

In allergy, an adjuvant is a substance or compound that is co-administered with the allergen extract and has the ability to increase allergen immunogenicity and/or to modulate the immune response [9]. Adjuvants are used to

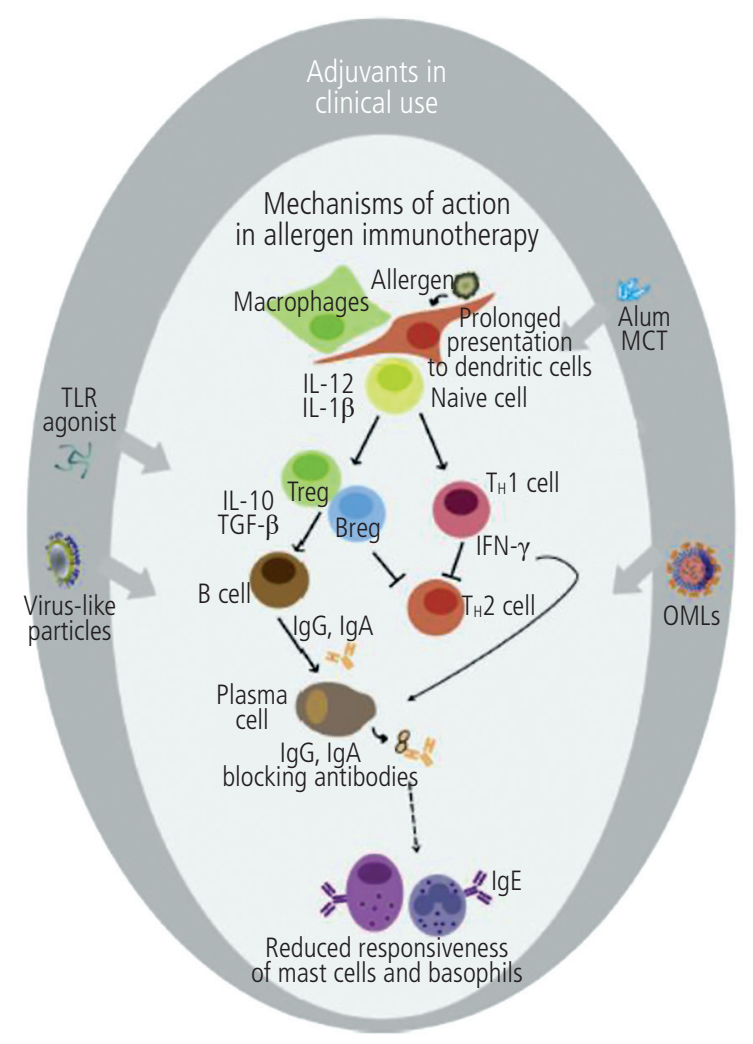

Figure 1. Immune mechanisms of allergen-specific immunotherapy and adjuvants. Modified from Chesné et al, 2016 [49]. MCT indicates microcrystalline tyrosine; TLR, Toll-like receptor; OML, oligomannose-coated liposomes.

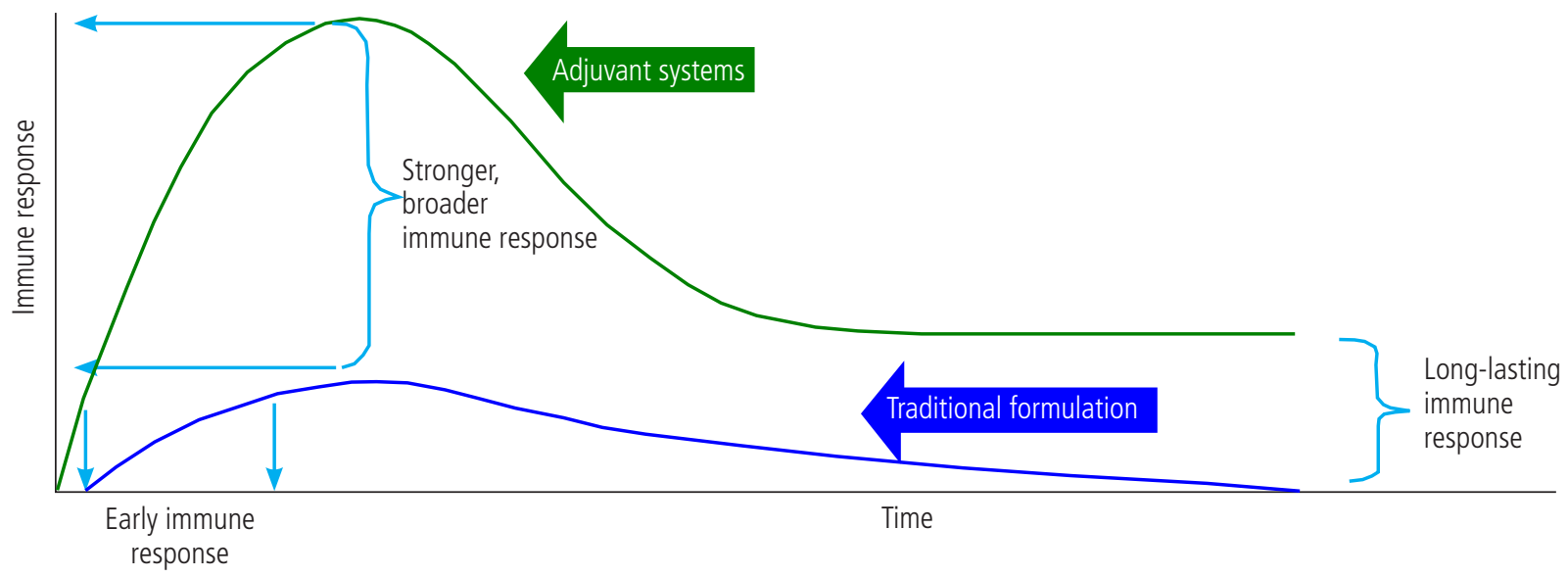

Figure 2. Advantages of adjuvant-formulated vaccines. Modified from Pulendran et al, 2006 [10]. 
Table 1. Adjuvants in Allergen-Specific Immunotherapy

DELIVERY SYSTEMS
Aluminum hydroxide
Calcium phosphate
Microcrystalline tyrosine
IMMUNOMODULATORY AGENTS
Monophosphoryl lipid A
ADJUVANTS UNDER RESEARCH
Immunostimulatory sequences
Nanoparticles
Liposomes
Virus-like particles
Immunostimulatory complexes
Biodegradable polymers
Phosphatidylserine

induce a quicker, more potent, and longer-lasting immune response to AIT (Figure 2) [10]. They have been widely used to improve and simplify AIT, because they make it possible to reduce the number of doses needed. Furthermore, research is currently focused on finding more effective and safer compounds [9].

The ideal adjuvant should be biodegradable, stable, sustainable, nontoxic, and cost-effective. It should also promote an appropriate immune response [11]. Currently, the desired characteristics of the ideal adjuvant for AIT have been extended: it should also combine optimal physiochemical properties (eg, particle morphology and adsorption capacity) with biological activity properties (eg, enhancing IgG4 antibody titers and avoiding the $\mathrm{T}_{\mathrm{H}} 2$-type immune response) [12]. In addition, the European Medicines Agency released a guideline on adjuvants in vaccines for human use; the quality and nonclinical (including toxicity) chapters are applicable to AIT [13].

Different classifications of adjuvants have been proposed according to the nature of the compound or the mechanisms of action. According to authors such as O'Hagan et al [14], Klimek et al [12], and Moreno et al [15], from a functional point of view, adjuvants can be categorized as delivery systems, which modulate antigen presentation, and immunomodulatory agents, which are direct modulators of the immune response, although some adjuvants could be included in both categories [14]

Many compounds have proved their potential as adjuvants. However, a few have been studied for AIT (Table 1), and an even smaller number have reached the clinical development stage. Only 4 compounds are used in currently marketed AIT products: aluminum hydroxide, calcium phosphate, microcrystalline tyrosine (MCT), and monophosphoryl lipid A (MPL). The first 3 adjuvants are considered to be delivery systems, although they may also have immunomodulatory properties. In turn, MPL is an immunostimulatory agent. The mechanisms of action of each adjuvant are described below.

\section{Delivery Systems}

These systems have been widely used for many years and are considered first-generation adjuvants. They have very different structures and compositions but quite similar mechanisms of action [16]. Traditionally, they have been considered particulate carriers that deliver allergens to immune cells and prolong allergen presence at the injection site [14]. This slow release of allergen (depot effect) increases the exposure time of the allergen to the immune system, stimulating the production of high and sustained antibody titers. However, it has been suggested that the depot effect is not the primary mode of action, although it is related to adjuvant tolerability [12].

\subsection{Aluminum Hydroxide}

Aluminum compounds have been used as adjuvants for almost a century [9] and remain the most frequently used adjuvants in vaccination and immunotherapy [17]. Aluminum as an adjuvant in AIT enhances allergen immunogenicity and tolerability but also raises IgG and IgE titers [12]. However, despite its widespread use, its exact mechanism of action as an adjuvant remains unknown. Available experimental evidence is scarce, although the increased humoral immunity caused by aluminum adjuvants can be explained by 3 mechanisms. The first is the formation of a sustained antigen release depot, which would enhance antibody production [18] and could contribute to the safety of AIT [17]. The second mechanism is the conversion of a soluble antigen into a particulate form and subsequent phagocytosis by antigen-presenting cells (APCs). The third mechanism is the induction of inflammation, which results in the recruitment and activation of APCs and antigen capture [18]. When injected, the aluminum-formulated allergen causes inflammation at the injection site. Immediately after injection, cells release chemokines and cytokines that recruit cells of the innate immune system (monocytes, eosinophils, neutrophils, and others) to the injection site. Moreover, damaged tissue releases the endogenous danger signal uric acid. Subsequently, monocytes react to aluminum and uric acid through activation of the nucleotide-binding and oligomerization domain-, leucine-rich repeat- and pyrin domain-containing 3 (NLRP3, also known as NALP3) inflammasome [19], which is a caspase-1 activating complex that induces inflammation. Monocytes capture the allergen and process it in conjunction with the major histocompatibility complex (MHC) I and MHC II molecules, while migrating to the draining lymph nodes [19].

However, aluminum is subject to limitations, which are related to its potential adverse effects reviewed elsewhere [19]. Since it can induce a $\mathrm{T}_{\mathrm{H}} 2$ response [17], it is used in experimental animal models of allergic asthma, allergic rhinitis, and eosinophilic esophagitis [19]. This $\mathrm{T}_{\mathrm{H}} 2$ polarization may constitute a suboptimal effect in AIT.

Other limitations of aluminum are potential acute and chronic inflammation at the injection site [17], as observed in more than $15 \%$ of patients of a large observational study [20]. With regard to systemic adverse events, aluminum has low biodegradability and could accumulate after repeated administration in AIT [21]. In addition, it has been suggested 
that aluminum adjuvants could be related to the autoimmune/ autoinflammatory syndrome induced by adjuvants (ASIA). However, current evidence does not support a relationship between aluminum and ASIA [22]. Although no clear associations between vaccinations using aluminum adjuvants and serious adverse events have been found to date, routine use of aluminum adjuvants in AIT is questionable [23]. There is increasing concern about chronic aluminum toxicity, and authorities from different countries are inspecting the safety of aluminum [17].

\subsection{Calcium Phosphate}

Calcium phosphate is a mineral salt that is used as a depot adjuvant in AIT. It is used less commonly than aluminum hydroxide [12], although it may offer some advantages because it is naturally present in the body and is biodegradable and biocompatible. Furthermore, results of studies in humans suggest that calcium phosphate is able to adsorb antigens, does not induce IgE production, and markedly increases IgG levels [24].

Calcium phosphate could be an alternative to aluminum adjuvants [24]. However, in animal models, it also induced local adverse reactions and showed lower adjuvant activity than aluminum [25].

\subsection{Microcrystalline Tyrosine}

L-tyrosine is a biodegradable amino acid of natural origin with ideal adjuvant properties [26]. The patent of its depot formulation, MCT, is registered for use as an immunomodulator and adjuvant.

Antigen-adjuvant adsorption affects vaccine potency, and MCT has shown adsorption capacities higher than 95\% for allergens and MPL, with favorable stability [27]. Given that the half-life of MCT is 48 hours [26], allergen release is sustained and immune exposure is prolonged. MCT is naturally metabolized (biodegradable): L-tyrosine is metabolized after release from the injection site, thus reducing the risk of granulomas observed with other depot adjuvants [26]. Moreover, MCT enhances IgG production with limited increases in IgE levels [26].

MCT immunogenicity was studied in $\mathrm{BALB} / \mathrm{c}$ mice immunized with ovalbumin adsorbed to MCT or aluminum. Upon a second exposure to ovalbumin, the increase in $\mathrm{T}_{\mathrm{H}} 1$ cytokines (interferon $\gamma[$ IFN- $\gamma]$ ) and IL-10 was higher with MCT. IgG1 and IgG2a production was similar with both adjuvants, whereas IgE production was higher with aluminum. Thus MCT was considered a biodegradable alternative to aluminum [28].

Finally, preclinical and clinical studies have suggested that L-tyrosine is safe as an adjuvant in humans. No genotoxicity, mutagenicity, carcinogenicity, or teratogenicity has been observed. MCT has shown good local and systemic tolerability in children and adults. It is contraindicated in tyrosine metabolism disorders [26].

\section{Immunomodulatory Agents}

Immunomodulatory agents consist of a heterogeneous group of products that act directly on immune cells to modulate their antigen response. Their mechanism of action is based on the activation of innate immune receptors on macrophages, dendritic cells, and other APCs [14].

The so-called danger signals trigger innate and adaptive responses by the immune system. These signals include pathogen-associated molecular patterns (PAMPs) and damageassociated molecular patterns. PAMPs are absent in the host and are exogenous danger signals that induce signals associated with innate immunity. Major PAMPs are microbial nucleic acids, lipoproteins, surface glycoproteins, and membrane components such as lipopolysaccharide. Pathogen recognition receptors recognize PAMPs and include Toll-like receptors (TLRs), nucleotide-binding oligomerization domain-like receptors, and other types of receptor [29]. TLRs recognize PAMPs and activate many intracellular signaling pathways that produce proinflammatory and antimicrobial responses, resulting in the production of cytokines, chemokines, cell adhesion molecules, and immunoreceptors [29]. The immune response differs according to the TLR-mediated activated pathway: $\mathrm{T}_{\mathrm{H}} 1$ response for TLR -4 and TLR- 9 , and $\mathrm{T}_{\mathrm{H}} 2$ response for TLR-2 [30]. Second-generation adjuvants are synthetically bacterial derivatives that interact with TLRs on immune cells. They are not delivery systems with a depot effect, but immunomodulators that potentiate immune cells/pathways [12]. The most studied second-generation adjuvants in AIT are MPL and immunostimulating sequences (ISSs) of synthetic oligodeoxynucleotides (ODNs) containing unmethylated cytosine-phosphorothioate-guanine $(\mathrm{CpG})$ motifs.

\subsection{Monophosphoryl Lipid A}

The only second-generation adjuvant approved for AIT is MPL (GSK, United Kingdom), a detoxified derivative of lipopolysaccharide of Salmonella minnesota R595. Lipopolysaccharide molecules are found in the outer membrane of gram-negative bacteria and are another example of PAMPs. Recognition of lipopolysaccharide by pathogen recognition receptors of APCs elicits a potent immune response [12]. The immunological effects of lipopolysaccharide are mediated by its diphosphoryl lipid A moiety, which is toxic to most animal species. However, MPL is obtained by a hydrolytic process followed by chromatography and has 1 phosphoryl group and 6 acyl side chains (lower fatty acid content) but no polysaccharide side group. Thus, MPL retains the immunomodulatory properties of lipopolysaccharide but without its toxicity [12].

MPL was the first TLR agonist included in a licensed human vaccine [16]. It has been used in many vaccine formulations, notably in hepatitis B and human papillomavirus vaccines [31], and has been delivered in millions of licensed vaccines with a low incidence of adverse events. In addition, since 1999, allergic patients have been treated with allergy vaccines that incorporate MPL as an adjuvant [32]. MPL has also been included in clinical trials with Plasmodium falciparum vaccines [33] and herpes simplex virus type 2 vaccines [34]. Moreover, the United States Food and Drug Administration recently approved an MPL-containing vaccine for the prevention of herpes zoster [35].

MPL interacts with TLR-4. After stimulation of these receptors by MPL, dendritic cells mature and produce 
cytokines, especially IL-12, which activate T cells to mature into the $T_{H} 1$ phenotype [36]. In an in vitro study, peripheral blood mononuclear cells obtained from 13 patients with grass pollen allergy (Phleum pratense) were cultured with a $P$ pratense extract and MPL. Allergen-induced IFN- $\gamma$ production increased $(P<.001)$, while IL-5 production decreased $(P<.01)$. When a neutralizing antibody against IL-12 was added, 95\% inhibition of MPL-induced IFN- $\gamma$ production was observed. This study showed that MPL deviated $\mathrm{T}_{\mathrm{H}} 2$ cell responses to $\mathrm{T}_{\mathrm{H}} 1$ responses in an IL-12 and monocyte-dependent way [37].

\section{Adjuvants Under Research}

\subsection{Immunostimulatory Sequences}

Bacterial DNA is a clear example of a PAMP. It contains unmethylated $\mathrm{CpG}$ motifs, which are rare in human DNA. During infection, these motifs are recognized, and a protective immune response is triggered. Synthetic oligodeoxynucleotides containing unmethylated $\mathrm{CpG}$ motifs (CpG-ODNs) are ISSs that mimic the immunostimulatory activity of bacterial DNA [38]. CpG-ODNs are recognized by the pathogen recognition receptor TLR-9 on B-cells, dendritic cells, and other cell types and promote $\mathrm{T}_{\mathrm{H}} 1$ and Treg responses [39]. Although a relatively old concept, $\mathrm{CpG-ODNs} \mathrm{have} \mathrm{emerged}$ recently as adjuvants in immunotherapy and have been used for different types of immunotherapies [40-42].

The several types of synthetic CpG-ODNs differ in terms of their structures and biological properties [38]. The ISS 5'-TGACTGTGAACGTTCGAGATGA-3', also known as ISS-1018, has been studied as an adjuvant in AIT. A proteinlinked immunostimulatory sequence 1018 (PLI-1018) was created with Amb a 1, the immunodominant allergen of ragweed pollen, and ISS-1018. In cultures of peripheral blood mononuclear cells from patients with ragweed allergy, the increase in IFN- $\gamma$ and the reduction in IL- 4 were higher with PLI-1018 than with Amb a 1 and free ISS-1018. These results suggested that ISS-1018 has strong cytokine-modulating activity when administered together with an antigen [43]. A vaccine composed of Amb a 1 conjugated with ISS-1018 was subsequently assessed in a randomized double-blind placebo-controlled phase 2 study. Patients with ragweed allergy $(n=25)$ received 6 weekly injections of vaccine or placebo before the first ragweed season and were followed for 2 consecutive seasons. Nasal scores were better in vaccinated patients during both seasons, suggesting that the vaccine had long-term clinical efficacy [44]. However, in a subsequent phase $2 \mathrm{~b}$ study ( $\mathrm{n}=738$ ), no differences were found between a vaccine composed of Amb a 1 conjugated with ISS-1018 and placebo, and the project was discontinued [45]. In any case, ISSs are still under investigation as adjuvants in AIT. Promising results have been reported for sublingual AIT using CpG-ODNs as adjuvants in a murine model of food allergy [46].

\subsection{Nanoparticles}

Nanoparticles are under research as new adjuvants/delivery systems in AIT. Nanoparticles protect the allergen from degradation, achieve high concentrations at the site of action, and prevent IgE recognition. They have a strong immunogenic effect with low allergenic potency $[47,48]$ and combine the potential of optimal allergen presentation [9] with intrinsic adjuvant properties [12].

Encapsulation of allergens into nanoparticles has great potential for enhancing AIT [47]. It maintains and even enhances allergen immunogenicity because it protects allergens from hydrolysis and/or enzymatic degradation [9]. It also protects against environmental factors such as a broad range of $\mathrm{pH}$ values and temperatures [49]. Furthermore, encapsulation prevents allergen recognition by IgE from mast cells or basophils, thus potentially reducing the risk of adverse events [48]. In addition, it offers the possibility of co-delivering the allergen and immunostimulatory agents such as $\mathrm{CpG}$ motifs or lipopolysaccharide derivatives [9]. Finally, it limits allergen capture to those cells that have the ability to phagocytose the nanoparticle [49]. Nanoparticles have shown an advantage as adjuvants in oral immunotherapy against food allergens in animal models [50-52].

Other currently investigated adjuvants include liposomes, virus-like particles, and polymers. Here, we briefly describe their main features.

\subsubsection{Liposomes}

Liposomes are synthetic spheres composed of lipid bilayers. They can encapsulate allergens and act as both delivery systems and adjuvants. Initial clinical studies suggested that liposomes were not appropriate for AIT. However, in a randomized, double-blind, placebo-controlled trial in 55 patients with allergic asthma treated with a liposomeencapsulated extract of Dermatophagoides pteronyssinus, increased specific IgG, IgG1, and IgG4, decreased sputum eosinophils, and lower clinical scores were observed in vaccinated patients [53]. Newer liposome formulations are promising [48], although no safety data have been reported to date [54].

\subsubsection{Virus-Like Particles}

Virus-like particles (VLPs) are formed by a high number of copies of a viral capsid protein that mimics a viral scaffold with repetitive features [12]. Allergens can be conjugated onto VLPs, which are recognized as PAMPs by the human innate humoral immune system [12], even without $\mathrm{T}$ cell cooperation [55].

A peptide sequence of Der $\mathrm{p} 1$ was covalently coupled to a VLP derived from the bacteriophage $\mathrm{Q} \beta$ coat proteins. A significant increase in specific $\mathrm{IgG}$ was observed after administration of Der $p 1$ VLPs to healthy volunteers [56]. A house dust mite allergen preparation combined with a VLP adjuvant consisting of the bacteriophage $\mathrm{Q} \beta$ coat proteins filled with the CpG G10 (QbG10) was subsequently administered to patients with house dust mite allergy. Specific IgG also increased, and symptoms of rhinitis and allergic asthma were significantly improved [57]. In a third study, 299 patients with house dust mite allergy received QbG10 alone or placebo without coadministration of allergen. However, scores for rhinoconjunctivitis and quality of life were significantly 
better in patients treated with a high dose of this allergen-free immunomodulator than in those treated with placebo [58]. In a more recent double-blind, randomized study in patients with mild-to-moderate persistent allergic asthma, treatment with QbG10 improved asthma symptoms, salbutamol use, and the Asthma Control Questionnaire score [59]. These results suggest that allergens might not be needed for AIT [55]. Other ongoing studies of VLPs in AIT include a trial of a VLPcontaining peanut allergy vaccine [60]. In addition, AIT with VLPs has proven safe and well-tolerated in clinical trials [55].

\subsubsection{Biodegradable Polymers}

Polymeric nanoparticles, especially the biodegradable ones, have great potential as drug delivery systems [49]. The most studied natural biodegradable polymer in AIT is chitosan, a natural mucoadhesive polysaccharide derived from crustacean cells. It is biocompatible, biodegradable, and nontoxic. It increases the penetration of macromolecules across the mucosa [12]. In turn, the most extensively studied synthetic biodegradable polymer in AIT is the polylactideco-glycolic acid (PLGA), a polyester used for preparation of nanoparticles. PLGA is biocompatible, biodegradable, and safe [12]. However, chitosan and PLGA have only been studied in animal models [49].

\subsection{Phosphatidylserine}

Phosphatidylserine (PS) derivatives are being studied as potential biological immunostimulatory agents. PS is known to be a surface marker for apoptosis, although it is also essential for downregulation of macrophages [12].
Three PS derivatives could potentially be useful in AIT: dioleoyl PS, lyso oleoyl PS, and stearoyl arachidonoyl PS. Their effects on immunoglobulins are different: dioleoyl PS stimulates IgG and IgA, lyso oleoyl PS stimulates IgA, and stearoyl arachidonoyl PS inhibits IgE. They have been shown not to be mutagenic or cytotoxic [12].

\section{Comparison of Adjuvants in AIT}

Table 2 shows the mechanisms of action and the main advantages and disadvantages of the 4 adjuvants currently used in AIT.

The clinical and immunological efficacy of different adjuvants for AIT were compared in a murine model. First, a new murine model of allergic bronchial inflammation by sensitization to olive pollen (Olea europaea) was developed [61]. Second, the immune response was assessed in sensitized mice treated with $O$ europaea coadministered with different adjuvants (aluminum hydroxide, calcium phosphate, MPL, and ISSs). The results showed that specific IgE was significantly higher in the group of mice treated with O europaea and aluminum hydroxide, and significantly lower in mice treated with $O$ europaea plus ISS or MPL. Moreover, IFN- $\gamma$ levels were significantly higher in mice that received O europaea and ISSs or MPL than in those that received other adjuvants. As for bronchial hyperreactivity and cellular lung inflammation, a significant improvement was only observed mice treated with $O$ europaea and bacterial derivatives (MPL and ISSs) [62].

Table 2. Adjuvants Currently Used in Allergen-Specific Immunotherapy

\begin{tabular}{|c|c|c|c|}
\hline Type & Mechanism of action & Advantages & Disadvantages \\
\hline \multicolumn{4}{|l|}{ DELIVERY SYSTEMS } \\
\hline Aluminum hydroxide & $\begin{array}{l}\text { Depot effect } \\
\text { Sustained antigen release } \\
\text { Conversion of soluble antigen into } \\
\text { a particulate form and subsequent } \\
\text { phagocytosis by APCs } \\
\text { Induction of inflammation }\end{array}$ & Widely used & $\begin{array}{l}\text { Nonbiodegradable } \\
\mathrm{T}_{\mathrm{H}} 2 \text { polarized } \\
\text { Local adverse events } \\
\text { Safety concerns }\end{array}$ \\
\hline Calcium phosphate & $\begin{array}{l}\text { Depot effect } \\
\text { Mechanism of action: similar to } \\
\text { aluminum hydroxide }\end{array}$ & $\begin{array}{l}\text { Naturally present in the organism, } \\
\text { biodegradable, and biocompatible }\end{array}$ & $\begin{array}{l}\text { Lower adjuvant activity } \\
\text { compared to aluminum }\end{array}$ \\
\hline Microcrystalline tyrosine & $\begin{array}{l}\text { Depot effect } \\
\text { Inflammasome activation }\end{array}$ & $\begin{array}{l}\text { Biodegradable } \\
\text { No significant IgE increase } \\
\text { Good local and systemic tolerability }\end{array}$ & $\begin{array}{l}\text { Contraindicated in tyrosine } \\
\text { metabolism disorders }\end{array}$ \\
\hline \multicolumn{4}{|c|}{ IMMUNOMODULATORY AGENTS } \\
\hline Monophosphoryl lipid A & TLR-4 agonist & $\begin{array}{l}\text { Same immunomodulatory properties } \\
\text { of lipopolysaccharide but without } \\
\text { its toxicity } \\
\text { Dose sparing effects } \\
\text { The only second generation adjuvant } \\
\text { approved for allergen immunotherapy }\end{array}$ & $\begin{array}{l}\text { Expensive, } \\
\text { sophisticated procedure }\end{array}$ \\
\hline
\end{tabular}

${ }^{a}$ Abbreviations: APC, antigen-presenting cell; TLR, Toll-like receptor. 


\section{Conclusion}

Use of adjuvants can enhance the efficacy of AIT and simplify treatment regimens. Various adjuvants are currently available for AIT. First-generation adjuvants, ie, delivery systems with a depot effect, are widely used, although some drawbacks have been identified, especially for aluminum hydroxide. Second-generation adjuvants comprise immunomodulatory agents. MPL is the first of these new adjuvants that was approved for AIT, although various adjuvants for AIT are currently being investigated.

Adjuvant type affects the immune response to AIT and, therefore, to clinical results. On choosing the right product for AIT, we should take into account not only the characteristics of the allergen extract, but also the adjuvant added to the extract.

A better understanding of the mechanisms of both AIT and adjuvants, together with more data on safety and tolerability, will prove useful when designing new approaches to the management of allergic diseases.

\section{Acknowledgments}

The authors thank Content Ed Net, Madrid, for editorial and writing assistance.

\section{Funding}

Editorial and writing assistance was funded by Allergy Therapeutics Ibérica.

\section{Conflicts of Interest}

$\mathrm{JMZ}$ has received lecture fees from Stallergenes and Allergy Therapeutics. MF has no conflicts of interest. ID has received payment for lectures, including service on speakers' bureaus for Stallergenes and Allergy Therapeutics, and consultancy fees from Stallergenes. JLJ is an employee of Allergy Therapeutics Ibérica.

\section{References}

1. Bousquet J, Lockey R, Malling HJ. Allergen immunotherapy: therapeutic vaccines for allergic diseases. A WHO position paper. J Allergy Clin Immunol. 1998;102:558-62.

2. Jutel M, Van de Veen W, Agache I, Azkur KA, Akdis M, Akdis CA. Mechanisms of Allergen-Specific Immunotherapy and Novel Ways for Vaccine Development. Allergol Int. 2013;62:425-33.

3. Dhami S, Kakourou A, Asamoah F, Agache I, Lau S, Jutel M, et al. Allergen immunotherapy for allergic asthma: A systematic review and meta-analysis. Allergy. 2017;72:1825-48.

4. Dhami S, Nurmatov U, Arasi S, Khan T, Asaria M, Zaman H, et al. Allergen immunotherapy for allergic rhinoconjunctivitis: $A$ systematic review and meta-analysis. Allergy. 2017;72:1597-631.

5. Kristiansen M, Dhami S, Netuveli G, Halken S, Muraro A, Roberts $G$, et al. Allergen immunotherapy for the prevention of allergy: A systematic review and meta-analysis. Pediatr Allergy Immunol. 2017;28:18-29.

6. Nurmatov U, Dhami S, Arasi S, Pajno GB, Fernandez-Rivas M, Muraro $A$, et al. Allergen immunotherapy for IgE-mediated food allergy: a systematic review and meta-analysis. Allergy. 2017;72:1133-47

7. Dhami S, Zaman H, Varga E-M, Sturm GJ, Muraro A, Akdis $C A$, et al. Allergen immunotherapy for insect venom allergy: a systematic review and meta-analysis. Allergy. 2017;72:342-65.

8. Jutel M, Agache I, Bonini S, Burks AW, Calderon M, Canonica W, et al. International Consensus on Allergen Immunotherapy II: Mechanisms, standardization, and pharmacoeconomics. J Allergy Clin Immunol. 2016;137:358-68.

9. Gamazo C, D'Amelio C, Gastaminza G, Ferrer M, Irache JM. Adjuvants for allergy immunotherapeutics. Hum Vaccin Immunother. 2017;13:2416-27.

10. Pulendran B, Ahmed R. Translating Innate Immunity into Immunological Memory: Implications forVaccine Development. Cell. 2006;124:849-63.

11. Aguilar JC, Rodríguez EG. Vaccine adjuvants revisited. Vaccine. 2007;25:3752-62

12. Klimek L, Schmidt-Weber CB, Kramer MF, Skinner MA, Heath MD. Clinical use of adjuvants in allergen-immunotherapy. Expert Rev Clin Immunol. 2017;13:599-610.

13. Committee for medicinal products for human use (CHMP). Guideline on adjuvants in vaccines for human use 2005. http://www.ema.europa.eu/docs/en_GB/document_library/ Scientific_guideline/2009/09/WC500003809.pdf (accessed September 4, 2018).

14. O'Hagan DT, De Gregorio E. The path to a successful vaccine adjuvant - 'The long and winding road.' Drug Discov Today. 2009; 14:541-51.

15. Moreno C, Monsalve R, Baeza M, Zubeldia J. [Future perspectives in immunotherapy]. In: Peláez-Hernández, editor. Tratado Alergol Spanish Soc Allergol Clin Immunol, Madrid, Spain: Editorial Ergon; 2007, p. 397.

16. O'Hagan DT, Fox CB. New generation adjuvants - From empiricism to rational design. Vaccine. 2015;33:B14-20.

17. Jensen-Jarolim E. Aluminium in Allergies and Allergen immunotherapy. World Allergy Organ J. 2015;8:7

18. Kool M, Soullié T, van Nimwegen M, Willart MAM, Muskens $F$, Jung $S$, et al. Alum adjuvant boosts adaptive immunity by inducing uric acid and activating inflammatory dendritic cells. J Exp Med. 2008;205:869-82.

19. Lambrecht BN, Kool M, Willart MA, Hammad H. Mechanism of action of clinically approved adjuvants. Curr Opin Immunol. 2009;21:23-9.

20. Hauswald B, Wolf H, Becker F, Becker S, Schnitker J, Wüstenberg E. Tolerability of a new fast updosed immunologically enhanced subcutaneous immunotherapy formulation with an optimized allergen to adjuvant ratio under routine practice conditions: a noninterventional observational study. J Investig Allergol Clin Immunol. 2013;23:471-7.

21. McDougall SA, Heath MD, Kramer MF, Skinner MA. Analysis of aluminium in rat following administration of allergen immunotherapy using either aluminium or microcrystallinetyrosine-based adjuvants. Bioanalysis. 2016;8:547-56.

22. Ameratunga $R$, Gillis $D$, Gold $M$, Linneberg $A$, Elwood JM. Evidence Refuting the Existence of Autoimmune/ Autoinflammatory Syndrome Induced by Adjuvants (ASIA). J Allergy Clin Immunol Pract. 2017;5:1551-5.

23. Willhite CC, Karyakina NA, Yokel RA, Yenugadhati $N$, Wisniewski TM, Arnold IMF, et al. Systematic review of 
potential health risks posed by pharmaceutical, occupational and consumer exposures to metallic and nanoscale aluminum, aluminum oxides, aluminum hydroxide and its soluble salts. Crit Rev Toxicol. 2014;44 Suppl 4:1-80.

24. Masson J-D, Thibaudon M, Bélec L, Crépeaux G. Calcium phosphate: a substitute for aluminum adjuvants? Expert Rev Vaccines. 2017;16:289-99.

25. Goto N, Kato H, Maeyama J, Shibano M, Saito T, Yamaguchi $J$, et al. Local tissue irritating effects and adjuvant activities of calcium phosphate and aluminium hydroxide with different physical properties. Vaccine. 1997;15:1364-71.

26. Baldrick P, Richardson D, Wheeler AW. Review of L-tyrosine confirming its safe human use as an adjuvant. J Appl Toxicol. 2002;22:333-44.

27. Bell AJ, Heath MD, Hewings SJ, Skinner MA. The adsorption of allergoids and 3-0-desacyl-4'-monophosphoryl lipid A (MPL $®)$ to microcrystalline tyrosine (MCT) in formulations for use in allergy immunotherapy. J Inorg Biochem. 2015;152:147-53.

28. Leuthard D, Freiberger S, Weiss S, Duda A, Heath M, Skinner $M$, et al. Microcrystalline tyrosine as an adjuvant in allergy immunotherapy: a mouse study. Allergy. 2016;71 (S102):3256.

29. Tang D, Kang R, Coyne CB, Zeh HJ, Lotze MT. PAMPs and DAMPs: signal Os that spur autophagy and immunity. Immunol Rev. 2012;249:158-75.

30. Netea MG, Van der Meer JWM, Sutmuller RP, Adema GJ, Kullberg B-J. From the Th1/Th2 paradigm towards a Tolllike receptor/T-helper bias. Antimicrob Agents Chemother. 2005;49:3991-6.

31. Garçon N, Chomez P, Van Mechelen M. GlaxoSmithKline Adjuvant Systems in vaccines: concepts, achievements and perspectives. Expert Rev Vaccines. 2007;6:723-39.

32. Rosewich M, Lee D, Zielen S. Pollinex Quattro: An innovative four injections immunotherapy in allergic rhinitis. Hum Vaccin Immunother. 2013;9:1523-31.

33. Genito CJ, Beck Z, Phares TW, Kalle F, Limbach KJ, Stefaniak ME, et al. Liposomes containing monophosphoryl lipid A and QS21 serve as an effective adjuvant for soluble circumsporozoite protein malaria vaccine FMP013. Vaccine. 2017;35:3865-74.

34. Stanfield B, Kousoulas KG. Herpes Simplex Vaccines: Prospects of Live-attenuated HSV Vaccines to Combat Genital and Ocular infections. Curr Clin Microbiol Reports. 2015;2:125-36.

35. James SF, Chahine EB, Sucher AJ, Hanna C. Shingrix: The New Adjuvanted Recombinant Herpes Zoster Vaccine. Ann Pharmacother. 2018; 52:673-80.

36. Ismaili J, Rennesson J, Aksoy E, Vekemans J, Vincart B, Amraoui $Z$, et al. Monophosphoryl lipid A activates both human dendritic cells and T cells. J Immunol. 2002;168:926-32.

37. Puggioni F, Durham SR, Francis JN. Monophosphoryl lipid A (MPL) promotes allergen-induced immune deviation in favour of Th1 responses. Allergy. 2005;60:678-84. doi:10.1111/ j.1398-9995.2005.00762.x.

38. Bode C, Zhao G, Steinhagen F, Kinjo T, Klinman DM. CpG DNA as a vaccine adjuvant. Expert Rev Vaccines. 2011;10:499-511.

39. Fonseca $D E$, Kline JN. Use of $C p G$ oligonucleotides in treatment of asthma and allergic disease. Adv Drug Deliv Rev. 2009:61:256-62.

40. Majewska-Szczepanik M, Askenase PW, Lobo FM, Marcińska K, Wen L, Szczepanik M. Epicutaneous immunization with ovalbumin and CpG induces TH1/TH17 cytokines, which regulate IgE and IgG2a production. J Allergy Clin Immunol. 2016:138:262-73.

41. Srivastava KD, Siefert A, Fahmy TM, Caplan MJ, Li X-M, Sampson HA. Investigation of peanut oral immunotherapy with $\mathrm{CpG} /$ peanut nanoparticles in a murine model of peanut allergy. J Allergy Clin Immunol. 2016;138:536-43.

42. Givens BE, Geary SM, Salem AK. Nanoparticle-based CpG-oligonucleotide therapy for treating allergic asthma. Immunotherapy. 2018; 10:595-604.

43. Marshall JD, Abtahi S, Eiden JJ, Tuck S, Milley R, Haycock F, et al. Immunostimulatory sequence DNA linked to the Amb a 1 allergen promotes $\mathrm{T}(\mathrm{H}) 1$ cytokine expression while downregulating $T(H) 2$ cytokine expression in PBMCs from human patients with ragweed allergy. J Allergy Clin Immunol. 2001;108:191-7.

44. Creticos PS, Schroeder JT, Hamilton RG, Balcer-Whaley SL, Khattignavong $A P$, Lindblad $R$, et al. Immunotherapy with a Ragweed-Toll-Like Receptor 9 Agonist Vaccine for Allergic Rhinitis. N Engl J Med. 2006;355:1445-55.

45. Dynavax TOLAMBA(TM) Chamber Study Misses Primary Endpoint; Company Updates 2008 Financial Outlook (NASDAQ:DVAX) 2008. http://investors.dynavax.com/ releasedetail.cfm?releaseid=310795 (accessed September 17, 2018).

46. Rodriguez MJ, Mascaraque A, Ramos-Soriano J, Torres MJ, Perkins JR, Gomez F, et al. Pru p 3-Epitope-based sublingual immunotherapy in a murine model for the treatment of peach allergy. Mol Nutr Food Res. 2017;61:1700110.

47. De Souza Rebouças J, Esparza I, Ferrer M, Sanz ML, Irache JM, Gamazo C. Nanoparticulate adjuvants and delivery systems for allergen immunotherapy. J Biomed Biotechnol. 2012;2012:474605.

48. Pohlit $H$, Bellinghausen I, Frey $H$, Saloga J. Recent advances in the use of nanoparticles for allergen-specific immunotherapy. Allergy. 2017;72:1461-74.

49. Chesné J, Schmidt-Weber CB, Esser von-Bieren J. The Use of Adjuvants for Enhancing Allergen Immunotherapy Efficacy. Immunol Allergy Clin North Am. 2016;36:125-45.

50. Gamazo C, García-Azpíroz M, Souza Rebouças J De, Gastaminza G, Ferrer M, Irache JM. Oral immunotherapy using polymeric nanoparticles loaded with peanut proteins in a murine model of fatal anaphylaxis. Immunotherapy. 2017;9:1205-17.

51. Araújo Pereira $M$, de Souza Rebouças J, de Siqueira Ferraz Carvalho R, Luis de Redín I, Valera Guerra P, Gamazo C, et al. Poly(anhydride) nanoparticles containing cashew nut proteins can induce a strong Th1 and Treg immune response after oral administration. Eur J Pharm Biopharm. 2018;127:51-60.

52. Brotons-Canto A, Gamazo C, Martín-Arbella N, Abdulkarim M, Matías J, Gumbleton M, et al. Evaluation of nanoparticles as oral vehicles for immunotherapy against experimental peanut allergy. Int J Biol Macromol. 2018;110:328-35.

53. Basomba A, Tabar Al, de Rojas DHF, García BE, Alamar R, Olaguíbel JM, et al. Allergen vaccination with a liposomeencapsulated extract of Dermatophagoides pteronyssinus: a randomized, double-blind, placebo-controlled trial in asthmatic patients. J Allergy Clin Immunol. 2002;109:9438. 
54. Pfaar O, Bonini S, Cardona V, Demoly P, Jakob T, Jutel M, et al. Perspectives in allergen immunotherapy: 2017 and beyond. Allergy. 2018;73 Suppl 1:5-23

55. Kündig TM, Klimek L, Schendzielorz P, Renner WA, Senti G, Bachmann MF. Is The Allergen Really Needed in Allergy Immunotherapy? Curr Treat Options Allergy. 2015;2:72-82.

56. Kündig T, Senti G, Schnetzeler G, Wolf C, Prinzvavricka B, Fulurija $A$, et al. Der p 1 peptide on virus-like particles is safe and highly immunogenic in healthy adults. J Allergy Clin Immunol. 2006;117:1470-6.

57. Senti G, Johansen P, Haug S, Bull C, Gottschaller C, Müller P, et al. Use of A-type CpG oligodeoxynucleotides as an adjuvant in allergen-specific immunotherapy in humans: a phase I/lla clinical trial. Clin Exp Allergy. 2009;39:562-70.

58. Klimek L, Willers J, Hammann-Haenni A, Pfaar O, Stocker $H_{\text {, }}$ Mueller $P$, et al. Assessment of clinical efficacy of CYTO03QbG10 in patients with allergic rhinoconjunctivitis: a phase Ilb study. Clin Exp Allergy. 2011;41:1305-12.

59. Beeh K-M, Kanniess F, Wagner F, Schilder C, Naudts I, Hammann-Haenni A, et al. The novel TLR-9 agonist QbG10 shows clinical efficacy in persistent allergic asthma. J Allergy Clin Immunol. 2013;131:866-74.
60. Storni F, Zeltins A, Heath M, Kramer M, Skinner M, Zha L, et al. 0182. Development of a recombinant vaccine based on virus-like particles for the treatment of peanut allergy. Allergy. 2018;73:S105:102.

61. Conejero L, Higaki Y, Baeza ML, Fernández M, Varela-Nieto I, Zubeldia JM. Pollen-induced airway inflammation, hyperresponsiveness and apoptosis in a murine model of allergy. Clin Exp Allergy. 2007;37:331-8.

62. Vázquez de la Torre M, Baeza ML, Nájera L, Zubeldia JM. Comparative study of adjuvants for allergen-specific immunotherapy in a murine mode. Immunotherapy. 2018 Sept 24. doi: 10.2217/imt-2018-0072.

\section{Ignacio Dávila}

Servicio de Alergia

Hospital Universitario de Salamanca

E-mail: idg@usal.es 